\title{
IMPLEMENTATION OF THE SIMPLE ADDITIVE WEIGHTING METHOD FOR EMPLOYEE PERFORMANCE ASSESSMENT
}

\author{
Siti Aisyah \\ Politeknik Negeri Media Kreatif \\ https://polimedia.ac.id \\ sitiaisyah@polimedia.ac.id
}

\begin{abstract}
Abstrak
Proses penilaian kinerja karyawan, perusahaan telah menetapkan prosedur operasional standar. Dari sekian banyak standar, sulit bagi manajemen untuk memberikan bobot pada setiap standar. Oleh karena itu, diperlukan sistem pengambilan keputusan untuk meningkatkan kinerja dan produktivitas perusahaan. Sumber daya manusia harus mampu meningkatkan kinerja pegawai. Pengetahuan atau kemampuan profesional. Permasalahan penilaian saat ini, termasuk proses penilaian kinerja karyawan, masih menggunakan cara tradisional dan belum akurat. Penelitian dilakukan dengan menggunakan metode simple additive weighting (SAW). Hasil penelitian ini menunjukkan bahwa dengan menggunakan metode SAW, manajemen lebih cenderung memperhatikan evaluasi kinerja karyawan, serta lebih terorganisir dan efisien dalam mengevaluasi kinerja karyawan.
\end{abstract}

Kata Kunci: Metode Simple Additive Weighting, metode SAW, Penilaian Kinerja Karyawan, Sistem Penunjang Keputusan

\begin{abstract}
In the process of evaluating employee performance, the company has established standard operating procedures. Of the many standards, it is difficult for management to give weight to each standard. Therefore, a decision-making system is needed to improve company performance and productivity. Human resources must be able to improve employee performance. Professional knowledge or ability. The current appraisal problem, including the employee performance appraisal process, is still using the traditional and not yet accurate method. The research was conducted using the simple additive weighting (SAW) method. The results of this study indicate that by using the SAW method, management is more likely to pay attention to employee performance evaluation, and is more organized and efficient in evaluating employee performance.
\end{abstract}

Keywords: Simple Additive Weighting Method, SAW method, Employee Performance Assessment, Decision Support System

\section{INTRODUCTION}

A company carrying out business activities, definitely requires human resources (HR) who have qualified and competent expertise in their fields and must be in accordance with the company's main objectives. In this case, employees have their respective duties and responsibilities that have been assigned to them, but not all employees have good performance (Hidayati, Purwanto, \& Yuwono, 2011). This is why companies need to evaluate the performance of their employees (Ayun, 2011), Because from the evaluation it can be seen whether the employee's performance is in accordance with the realization of company goals. Employee performance appraisal itself is a systematic study of employee working conditions that is carried out formally associated with work standards that have been determined by the company (Muhdar HM, 2012; Ponijan, 2012). From this assessment, it will be known whether the employee's work is adequate and in accordance with performance standards, and recommendations for improvement can be made in the future. The activity of assessing performance begins with identifying the organization's goals and then conducting a performance analysis to determine the organization's management's expectations of performance. At the end of the period, the assessment team carries out its assessment activities by measuring performance and evaluating, then comparing work findings with work targets, then discussing and communicating the results of the assessment, finally discussing performance improvement program planning. The 
performance evaluation process, organizations can use a variety of different measures for planning, measuring, and evaluating organizations (Fatimah, 2017).

The company in conducting the employee performance appraisal process, the company has determined a lot of criteria, from many criteria it can be difficult for the management to give weight to each criterion, therefore a decision-making system is needed to improve performance productivity in a company, then human resources must have expertise or competence to improve employee performance.

Assessment problems that are currently being faced, including the employee performance appraisal process that still uses conventional methods is not yet accurate (Putra Riyanto \& Saragih, 2019) in the assessment of work performance, and the absence of a special method to support the determination of the assessment of outstanding employees.

Mujiastuti in 2019 found that research conducted using the Simple Additive Weighting (SAW) method can be applied to regulate performance appraisals with the criteria of Attendance, attitude/ethics, time discipline, work quality, and work quantity. In the results of the performance appraisal trial, the predetermined criteria will produce a ranking number of employee performance appraisals. The calculation accuracy of the SAW method implemented in the Web-based employee performance appraisal decision support system application (Mujiastuti, Komariyah, \& Hasbi, 2019). Agustini and Eriska in 2019 said that employee performance appraisal using the FSAW method if the weight of the criteria is large but the value is small, it will be very influential for the assessment but if there is a deficiency in one of the criteria with a small weight, then it is not too influential for the assessment of several aspects of the criteria using the FSAW model. running well and can produce clear and fast weighting of assessment criteria and information compared to manual calculations (Agustini \& Ariska, 2019; Frieyadie, 2018).

Based on the description above, the SAW method can find the best alternative based on predetermined criteria (Setiadi, Yunita, \& Ningsih, 2018). The SAW method is often known as the weighted addition method (Frieyadie, 2016). The basic concept of the SAW method is to find the weighted sum of the performance ratings for each alternative on all attributes. The SAW method can help in deciding on a case, but the calculation using the SAW method is only the one that produces the largest value that will be selected as the best alternative.
The purpose of this research is to make it easier for the company to determine the quality and achievement of each employee through the performance assessment carried out.

\section{RESEARCH METHODS}

\section{Research Instruments}

An instrument is a tool used to do something. Instruments such as tools, which are used as research tools to collect data as processing materials. There are several instruments used in between.

\section{a. Interview}

This interview met with the Operations Manager CV. Creative Public Media. Researchers conducted unstructured interviews with those conducted directly (face to face). Where the researcher uses interview guidelines that are arranged systematically, this activity is intended to obtain information about the shortcomings and procedures for previous performance appraisals, so that researchers can determine the criteria and alternatives to be used.

\section{b. Observation (Observation)}

Observations made dating directly to CV. Creative Public Media collects data through direct observation.

\section{c. Questionnaire}

This is done by distributing a list of questionnaires to 30 employees to assess the respondents, namely, HRD Manager, IT Manager, Ops Manager, and Customer Care Manager at CV. Creative Public Media, the data taken includes the following aspects: 1) Quantity and Quality of Work, 2) Compliance with Compliance Principles, 3) Cooperation, 4) Work Spirit, 5) Work Discipline.

The above aspects are assessed using five measurement categories: Category 1 states Very Low (VL); Category 2 states Low (L); Category 3 states Enough (E); Category 4 states Height (H), Category 5 states Very High (VH).

\section{Research Variables}

This study uses a questionnaire instrument made using closed questions (Lubis, 2014). Each respondent can quickly and easily answer the questionnaire so that data from the questionnaire can be quickly analyzed systematically, and the same statement can be repeated easily. The questionnaire was made with a Likert scale. The scale used in the questionnaire uses a Likert scale with a positive value scale between Very Low (VL), Low (L), Enough (E, High (E), and Very High (VH). 
Table 1 follows the indicators of the research variables used as questionnaire questions:

Tabel 1 Kisi-Kisi Instrumen Penelitian

\begin{tabular}{|c|c|}
\hline Variabel & Pertanyaan \\
\hline $\begin{array}{l}\text { Quantity and } \\
\text { Quality of } \\
\text { Work }\end{array}$ & $\begin{array}{l}\text { 1. Produce and achieve quantity of work in } \\
\text { accordance with company targets } \\
\text { 2. Can do the job carefully, precisely and } \\
\text { according to the purpose }\end{array}$ \\
\hline Obey the & 3. Doing a job in accordance with the \\
\hline $\begin{array}{l}\text { Principle of } \\
\text { Compliance }\end{array}$ & $\begin{array}{l}\text { Standard Operational Procedure specified } \\
\text { in a job }\end{array}$ \\
\hline & 4. Carry out work with full responsibility \\
\hline Cooperate & $\begin{array}{l}\text { 5. Able to coordinate and communicate } \\
\text { well with leaders, colleagues and staff who } \\
\text { are their responsibility } \\
\text { 6. Can work in a team }\end{array}$ \\
\hline Spirit at work & $\begin{array}{l}\text { 7. Completing well a job that is the } \\
\text { responsibility given } \\
\text { 8. Complete work with better results }\end{array}$ \\
\hline $\begin{array}{l}\text { Work } \\
\text { Discipline }\end{array}$ & $\begin{array}{l}\text { 9. Carry out work based on the structure } \\
\text { of company provisions } \\
\text { 10. Adapting work quickly and precisely to } \\
\text { every new decision taken by the company }\end{array}$ \\
\hline
\end{tabular}

\section{Analysis Method}

The method used for analysis is the SAW method, often also known as the weighted addition method. The basic concept of the SAW method is to find the weighted sum of the performance ratings for each alternative on all attributes (Mahendra \& Aryanto, 2019). The SAW method requires the process of normalizing the decision matrix $(\mathrm{X})$ to a scale that can be compared with all available alternative ratings (Wolo, Servasius, Paseng, \& Roberth, 2019).

The research steps in the SAW method are 1) determine the criteria that will be used as a reference in decision making, namely Ci. 2) Determine the suitability rating of each alternative on each criterion. 3) Make a decision matrix based on the criteria ( $\mathrm{Ci}$ ), then normalize the matrix based on the equation that is adjusted to the type of attribute (profit attribute or cost attribute) in order to obtain a normalized matrix R. 4) Determination of normalization of the matrix based on a scale that can be compared with all alternative ratings available is in the matrix. The SAW equation is like equation 1 below.

$r_{i j}= \begin{cases}\frac{X_{i j}}{\operatorname{Max} X_{i j}} & \text { Jika } j \text { adalah atribut keuntungan (Benefit) } \\ \frac{\operatorname{Min} X_{i j}}{X_{i j}} & \text { Jika } j \text { adalah atribut biaya (Cost) }\end{cases}$
Explanation:

$r i j=$ Normalized performance rating value

$\mathrm{X} i=$ The attribute value of each criterion

Benefit= If the biggest value is the best

Cost= If the smallest value is the best where is the normalized performance rating of the alternative $\mathrm{Ai}$ on the attribute $\mathrm{Cj} ; \mathrm{i}=1,2, \ldots ., \mathrm{n}$.

The final result is obtained from each ranking process, namely the addition of the normalized matrix multiplication $\mathrm{R}$ with the weight vector so that the largest value is chosen as the best alternative (Ai) as the solution.

In this process, it becomes the product of the preference weights (W) with each column of the normalized matrix in one row according to the alternative solution of the choice given. Data was collected by giving questionnaires to 4 managers consisting of HR Manager, IT Manager, Operations Manager, and Finance Manager. The following questions were asked in the pre-test, after the application of the SAW method:

- Make it easier to evaluate employee performance?

- Provide precise and accurate analysis of employee performance appraisals?

- Provide benefits for the company?

- Using multiple parameters/variables?

- Provide accurate information?

- Assist the company in decision making?

- Provide information quickly?

The questionnaire process was measured using a Likert scale, which is a form of a rating scale of 1 to 5 with the following descriptions: Number 1 indicates Disagree (TS); Number 2 indicates Disagree (KS) Number 3 indicates Doubtful (R) Number 4 indicates Agree (S); Number 5 states Strongly Agree (SS)

\section{Pretest}

Table 2 is a pre-test calculation which has the initial steps taken before calculating the weight of each employee. After the data is obtained, the next step is to perform calculations with the data using the SAW method 
Table 2. Pre-Test

\begin{tabular}{|c|c|c|c|c|c|c|c|c|c|c|}
\hline \multirow{2}{*}{ No } & \multirow{2}{*}{ Name } & \multirow{2}{*}{ Position } & \multicolumn{7}{|c|}{ Question } & \multirow{2}{*}{ Total } \\
\hline & & & 1 & 2 & 3 & 4 & 5 & 6 & 7 & \\
\hline 1 & Nur Hardi & $\begin{array}{l}\text { Human Resources } \\
\text { Manager }\end{array}$ & 2 & 4 & 2 & 3 & 3 & 4 & 3 & 21 \\
\hline 2 & Tubagus Mardianto & $\begin{array}{l}\text { Information Technology } \\
\text { Manager }\end{array}$ & 2 & 4 & 3 & 2 & 2 & 2 & 4 & 19 \\
\hline 3 & Dewi Anggraini & Financial Manager & 3 & 3 & 2 & 3 & 4 & 3 & 4 & 22 \\
\hline 4 & M. Yudhana S. & Operational Manager & 3 & 2 & 4 & 2 & 3 & 4 & 4 & 22 \\
\hline
\end{tabular}

\section{RESULTS AND DISCUSSION}

\section{Problem analysis}

In this study, there are five criteria, namely 1) Quantity and Quality of Work, 2) Compliance with the Principles of Compliance, 3) Cooperation, 4) Morale, 5) Work Discipline. Each variable has an indicator. The number of indicators used is 10 questions, each variable has 2 questions.

\section{Data processing}

After the data is obtained, the next step is to perform calculations with the data using the SAW method. To analyze the data from the questionnaire, the following steps are carried out:

\section{a. Quantity and Quality of Work}

P1 = Produce and achieve the quantity of work in accordance with the company's target

P2 = Able to do work carefully, precisely and according to purpose

\section{b. Obey the Principle of Compliance}

P3 = Doing a job in accordance with the Standard Operational Procedure specified in a job P4 = Carry out work with full responsibility

\section{c. Cooperate}

P5 = Able to coordinate and communicate well with leaders, colleagues and staff who are their responsibility

P6 = Able to work in a team.

\section{d. Spirit at work}

P7 = Complete $\mathrm{a}$ job that is the responsibility given P8 $=$ Complete work with better results

\section{e. Work Discipline}

P9 = Carry out work based on the structure of company provisions

P10 = Adapting work quickly and precisely to every new decision taken by the company

From the predetermined weight fuzzy numbers can be converted to crisp numbers:

Very High $(\mathrm{ST})=1$; Height $(\mathrm{T})=0.75$; Enough $(\mathrm{C})=$ $0.5 ;$ Low $(\mathrm{R})=0.25$; Very Low $(\mathrm{SR})=0$

\section{Ranking.}

After the normalization process, the preference value for each alternative (Vi) is calculated with the average value of each leader, as shown in table 3 below..

Table 3 Ranking of the Combined Questionnaire

\begin{tabular}{rlrrrrrr}
\hline No & Alternative & HR Manager & $\begin{array}{c}\text { IT } \\
\text { Manager }\end{array}$ & $\begin{array}{r}\text { Financial } \\
\text { Manager }\end{array}$ & $\begin{array}{c}\text { Operational } \\
\text { Manager }\end{array}$ & Total & Rank \\
\hline 1 & Gunawan & 3,5 & 3,75 & 3,5 & 4,08 & 14,83 & 1 \\
2 & Wanti & 3,33 & 3,83 & 3,42 & 4 & 14,58 & 2 \\
3 & Hendrawan & 3,08 & 3,58 & 3,5 & 4,33 & 14,49 & 3 \\
4 & Fauzi & 3,29 & 3,5 & 3,63 & 3,83 & 14,25 & 4 \\
5 & Handayani & 3,42 & 3 & 3,92 & 3,75 & 14,09 & 5 \\
6 & Siswandi & 3,5 & 3,75 & 2,75 & 3,92 & 13,92 & 6 \\
7 & Nurlaela & 3,58 & 3,67 & 3,25 & 3,42 & 13,92 & 7 \\
8 & Setiorini & 3,42 & 2,92 & 3,67 & 3,75 & 13,76 & 8 \\
9 & Handayani & 3,13 & 3,58 & 3,42 & 3,58 & 13,71 & 9 \\
10 & Antono & 3,17 & 3,58 & 3,17 & 3,67 & 13,59 & 10 \\
11 & Junaedi & 3,13 & 3,08 & 3,33 & 3,83 & 13,37 & 11 \\
12 & Novianti & 3,5 & 3,33 & 3,25 & 3,25 & 13,33 & 12 \\
13 & Setiawan & 3,75 & 3,42 & 2,83 & 3,25 & 13,25 & 13 \\
14 & Budiono & 3,63 & 3,33 & 3,42 & 2,83 & 13,21 & 14 \\
15 & Ruswanto & 3,58 & 2,75 & 3,08 & 3,75 & 13,16 & 15 \\
16 & Rifai & 3,38 & 3,25 & 2,5 & 13,13 & 16 \\
\hline
\end{tabular}




\begin{tabular}{llrrrrrr}
\hline No & Alternative & HR Manager & $\begin{array}{c}\text { IT } \\
\text { Manager }\end{array}$ & $\begin{array}{l}\text { Financial } \\
\text { Manager }\end{array}$ & $\begin{array}{c}\text { Operational } \\
\text { Manager }\end{array}$ & Total & Rank \\
\hline 17 & Wandi & 3,29 & 3,08 & 3,17 & 3,58 & 13,12 & 17 \\
18 & Retno & 3,63 & 2,83 & 3,17 & 3,38 & 13,01 & 18 \\
19 & Fatmawati & 3,17 & 3,5 & 3,5 & 2,75 & 12,92 & 19 \\
20 & Soebagyo & 3,63 & 2,83 & 3,33 & 3,08 & 12,87 & 20 \\
21 & Sintawati & 2,21 & 3,17 & 3,75 & 3,58 & 12,71 & 21 \\
22 & Ernawati & 2,75 & 2,67 & 4,58 & 2,67 & 12,67 & 22 \\
23 & Mardianto & 3,5 & 2,83 & 2,92 & 3,25 & 12,5 & 23 \\
24 & Davina & 3,13 & 3,08 & 2,58 & 3,67 & 12,46 & 24 \\
25 & Ninawati & 3,38 & 3 & 3,75 & 2,25 & 12,38 & 25 \\
26 & Asep & 3,21 & 3 & 3,58 & 2,58 & 12,37 & 26 \\
27 & Nurazizah & 2,88 & 2,92 & 3,75 & 2,58 & 12,13 & 27 \\
28 & Indah & 2,88 & 2,92 & 3,75 & 2,25 & 11,8 & 28 \\
29 & Dina & 3,17 & 2,17 & 3,25 & 3,08 & 11,67 & 29 \\
30 & Riantina & 3,08 & 3,08 & 3,42 & 1,83 & 11,41 & 30 \\
\hline
\end{tabular}

\section{Results}

After the employee performance appraisal is implemented in CV. Creative Public Media, distributed questionnaires to the same 30 respondents to measure the impact of system implementation with questions and results of employee performance appraisals using the SAW method, can be seen as follows:

- Provide more accurate information?

- Provide more accurate information?

- More effective for assessing employee performance?

- Assist the company in decision making?

- Is it easy to use in evaluating employee performance?

- Provide more precise and accurate analysis?

- Can it be used to assess employee performance using several parameters?

- Can it provide benefits to the company?

\section{Hasil Post Test}

Table 4 Post Test

\begin{tabular}{|c|c|c|c|c|c|c|c|c|c|c|}
\hline \multirow{2}{*}{ No } & \multirow{2}{*}{ Name } & \multirow{2}{*}{ Position } & & & & & & & & \multirow{2}{*}{ Tota } \\
\hline & & & 1 & 2 & 3 & 4 & 5 & 6 & 7 & \\
\hline 1 & Nur Hardi & $\begin{array}{l}\text { Human Resources } \\
\text { Manager }\end{array}$ & 3 & 5 & 3 & 4 & 4 & 5 & 4 & 28 \\
\hline 2 & $\begin{array}{l}\text { Tubagus } \\
\text { Mardianto }\end{array}$ & $\begin{array}{l}\text { Information } \\
\text { Technology } \\
\text { Manager }\end{array}$ & 3 & 5 & 4 & 3 & 3 & 3 & 5 & 26 \\
\hline 3 & Dewi Anggraini & Financial manager & 4 & 4 & 3 & 4 & 5 & 4 & 5 & 29 \\
\hline 4 & M. Yudhana S. & $\begin{array}{l}\text { Operational } \\
\text { Manager }\end{array}$ & 4 & 3 & 5 & 3 & 4 & 5 & 5 & 29 \\
\hline
\end{tabular}

The results of the pre-test and post-test can be summarized in table 5: The results of the pre-test and post-test that have been calculated from the questionnaire given.

.Table 5. Comparison of Pre Test and Post Test Results

\begin{tabular}{lllcc}
\hline No & Employee Name & Position & Pre Test & Post Test \\
\hline 1 & Nur Hardi & Human Resources Manager & 21 & 28 \\
2 & Tubagus & Information Technology Manager & 19 & 26 \\
& Mardianto & & & \\
3 & Dewi Anggraini & Financial manager & 22 & 29 \\
4 & M. Yudhana S. & Operational Manager & 22 & 29 \\
\hline
\end{tabular}

Prior to the existence of a decision support system, employee performance appraisal was done manually. After the scores are recapitulated, then the calculation is carried out by adding up the values of each criterion, so that the total value of each employee is obtained. The examples of employee assessments that are carried out manually in table 6 are as follows:: 
Table 6 Results of Manual Employee Assessment

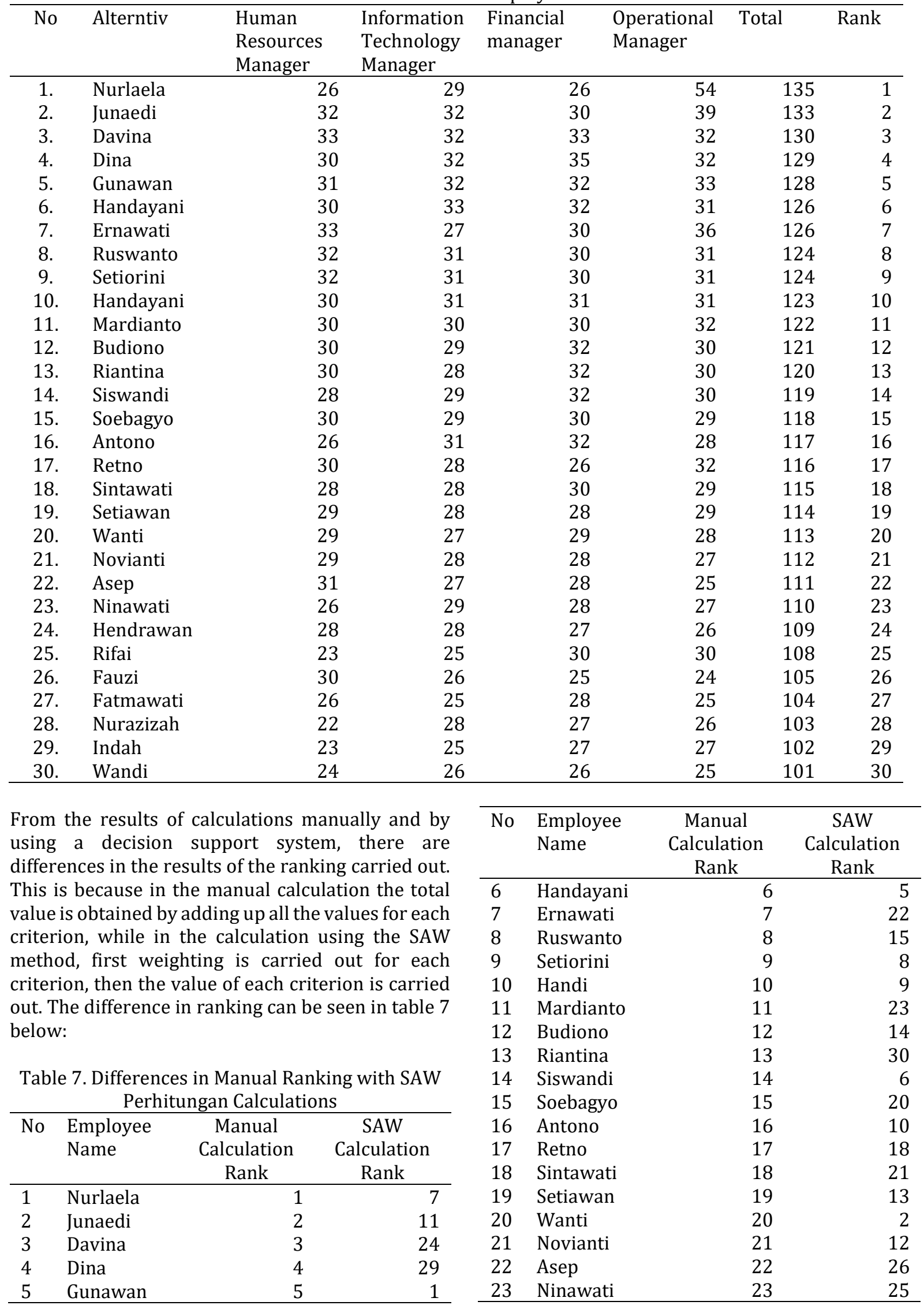




\begin{tabular}{llrr}
\hline No & $\begin{array}{l}\text { Employee } \\
\text { Name }\end{array}$ & $\begin{array}{c}\text { Manual } \\
\text { Calculation } \\
\text { Rank }\end{array}$ & $\begin{array}{c}\text { SAW } \\
\text { Calculation } \\
\text { Rank }\end{array}$ \\
\hline 24 & Hendrawan & 24 & 3 \\
25 & Rifai & 25 & 16 \\
26 & Fauzi & 26 & 4 \\
27 & Fatmawati & 27 & 19 \\
28 & Nurazizah & 28 & 27 \\
29 & Indah & 29 & 28 \\
30 & Wandi & 30 & 17 \\
\hline
\end{tabular}

If table 7 the difference in ranking with manual calculations and ranking with Simple Additive Weighting calculations, it is described in graphical form, Figure 1 will appear as follows:

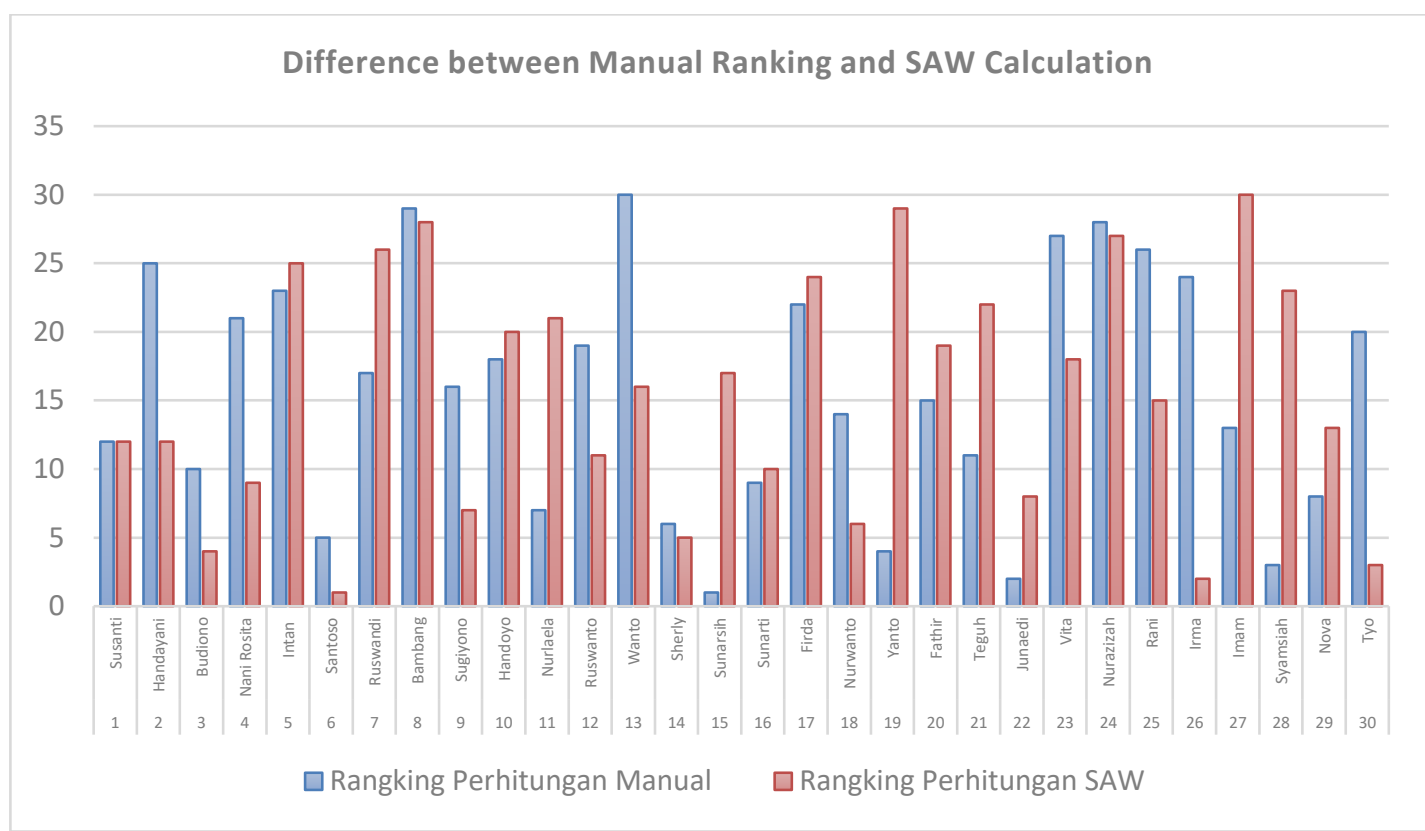

Figure 1 Comparison Graph of Manual Ranking against SAW

\section{CONCLUSION}

Using the SAW method has been felt by the management, which has an impact on making it easier to give an assessment weight to the performance of its employees as well as being more organized and efficient in conducting assessments. This SAW method has been tested for its validity level so that it gets the results of Mr. Gunawan as the best employee

\section{REFERENCE}

Agustini, F., \& Ariska, E. R. (2019). Penerapan Metode Simple Additive Weighting (Saw) Dengan Model Fuzzy Model Attribute Decision Making (Fmadm) Penilaian Kinerja Karyawan Dtpeduli. Jurnal Techno Nusa Mandiri, 16(1), 21-28.

https://doi.org/10.33480/techno.v16i1.107

Ayun, Q. (2011). Penilaian Kinerja (Performance Appraisal) pada Karyawan di Perusahaan.
Majalah Ilmiah INFORMATIKA, 2(3), 74-88. Retrieved from https://www.unaki.ac.id/ejournal/index.php /majalah-ilmiahinformatika/article/view/48

Fatimah, F. N. D. (2017). Panduan Praktis Evaluasi Kinerja Karyawan. Depok: Anak Hebat Indonesia.

Frieyadie, F. (2016). Penerapan Metode Simple Additive Weight (SAW) Dalam Sistem Pendukung Keputusan Promosi Kenaikan Jabatan. Pilar Nusa Mandiri: Journal of Computing and Information System, 12(1), 3745.

https://doi.org/10.33480/PILAR.V12I1.257

Frieyadie, F. (2018). Metode AHP Sebagai Penunjang Keputusan Untuk Penilaian Kinerja Kerja Karyawan SPBU. Jurnal Techno Nusa Mandiri, 15(1), 63-68. https://doi.org/10.33480/techno.v15i1.60

Hidayati, R., Purwanto, Y., \& Yuwono, S. (2011). Kecerdasan Emosi, Stres Kerja Dan Kinerja 
Karyawan. Jurnal Psikologi, 2(1), 91-96. Retrieved from https://ejournal.gunadarma.ac.id/index.php/ psiko/article/view/249

Mahendra, G. S., \& Aryanto, K. Y. E. (2019). SPK Penentuan Lokasi ATM Menggunakan Metode AHP dan SAW. Jurnal Nasional Teknologi Dan Sistem Informasi, 5(1), 49-56. https://doi.org/10.25077/TEKNOSI.V5I1.201 9.49-56

Muhdar HM. (2012). Stres Kerja Dan Kinerja Dalam Perspektif Teori Dan Bukti Empirik. Journal of Innovation in Business and Economics, 3(2), 111-120. https://doi.org/10.22219/JIBE.V3I2.2234

Mujiastuti, R., Komariyah, N., \& Hasbi, M. (2019). Sistem Penilaian Kinerja Karyawan Menggunakan Metode Simple Additive Weighting (SAW). JUST IT: Jurnal Sistem Informasi, Teknologi Informasi Dan Komputer, $9(2)$, 133-141. https://doi.org/10.24853/JUSTIT.9.2.133141

Ponijan, P. (2012). Penilaian Kinerja Dan Komitmen Dalam Etika Pemerintahan. Majalah Ilmiah
Widya, 29, 34-40. Retrieved from https://ejournal.jurwidyakop3.com/index.php/majala h-ilmiah/article/view/71

Putra Riyanto, N., \& Saragih, T. S. (2019). Reminder System dan Monitoring Proyek untuk Penilaian Kinerja Karyawan Berbasis Web. Jurnal Sisfokom (Sistem Informasi Dan Komputer), $\quad 8(2), \quad 172-183$. https://doi.org/10.32736/SISFOKOM.V8I2.6 34

Setiadi, A., Yunita, Y., \& Ningsih, A. R. (2018). Penerapan Metode Simple Additive Weighting(SAW) Untuk Pemilihan Siswa Terbaik. Jurnal Sisfokom (Sistem Informasi Dan Komputer), $\quad 7(2), \quad 104$. https://doi.org/10.32736/sisfokom.v7i2.572

Wolo, P., Servasius, A., Paseng, M., \& Roberth, Y. W. (2019). Sistem Pendukung Keputusan Penentuan Penerimaan Raskin Menggunakan Metode Simple Additive Weighting (Studi Kasus Kelurahan Kota Uneng). Teknika, 8(1), 74-77. https://doi.org/10.34148/TEKNIKA.V8I1.15 1 